UDK 821.163.42.09Lovrak, M.

821.163.42.09-94

\title{
Kornelija Kuvač-Levačić
}

Sveučilište u Zadru, Zadar, Hrvatska

klevac@unizd.hr

\section{Identitet subjekta u književničkoj autobiografiji i „biografija djela“6}

\section{Primjer romana Mate Lovraka Pero Kvržica među ljudima objavljenoga 2014. godine}

Izvorni znanstveni rad / original research paper

Primljeno/received 24. 9. 2015. Prihvaćeno/accepted 17. 6. 2016.

DOI: 10.21066/carcl.libri.2016-05(01).0004

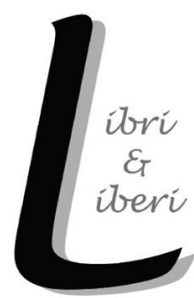

$\mathrm{U}$ radu se istražuje konstruiranje identiteta subjekta $\mathrm{u}$ autobiografskome diskursu Mate Lovraka na primjeru romana Pero Kvržica među ljudima (2014). Lovrakov autobiografski roman analizira se na razini predmetnoga teksta (tekst 2. stupnja) jer je građen intertekstualno, kao svojevrsni metatekst posredovanjem (autoreferencijalnoga) narativa o nastanku i recepciji najpoznatijega piščeva romana Družba Pere Kvržice, koji se pritom uzima kao referentni (odnosno tekst 1. stupnja). Rad otkriva postupke kojima se u Lovrakovu pripovijedanju ideja poistovjećenosti autora i njegova djela, posve suprotna od teorija koje takvo jedinstvo djelomice ili u potpunosti negiraju, dovodi na razinu simboličke funkcije produbljujući složeno pitanje tekstualnoga konstruiranja identiteta subjekta unutar autobiografskoga diskursa, i to osobito kada je njegov autor - književnik. Metafora „,biografije djela“" predstavlja temelj autorova konstrukta „sebe“, njegova je primarna identitetska odrednica, koja bitno utječe na sve glavne odrednice predmetnoga teksta. Lovrakov autobiografski diskurs posjeduje karakteristike otvorenoga znaka koji se, osim strukturalnim elementima i funkcijama, interpretativno poigrava i svim ostalim elementima književnoga komunikacijskoga lanca.

Ključne riječi: autobiografizam, biografija djela, identitet subjekta, književnička autobiografija, Mato Lovrak

Klasik hrvatske dječje književnosti Mato Lovrak napisao je, osim dviju autobiografija u užemu smislu riječi, ${ }^{1}$ i četiri autobiografska romana (Slamnati

\footnotetext{
Prema Vinku Brešiću Lovrak je još 1959. objavio Autobiografiju u 10 rečenica (u zagrebačkome tjedniku Globus), a njegovu drugu autobiografiju, koju uvrštava u svoju knjigu Autobiografije hrvatskih pisaca (1997.), nalazi prvi puta objavljenu u zborniku Dječji pisci o sebi (Sarajevo, 1963.), najvjerojatnije kao poseban zahtjev urednika Ahmeta Hromadžića (Brešić 1997: 834).
} 
krovovi, Gimnazijalac, Preparandist i Uzvišeno zvanje) koji navedenim redom kronološki tematiziraju razdoblja autorova života od djetinjstva, školovanja u gimnaziji i učiteljskoj školi do učiteljevanja u Hrvatskoj prije Drugoga svjetskoga rata. Predmet je ovoga istraživanja autobiografski roman Pero Kvržica među ljudima (2014) koji se čitateljima na koricama predstavlja kao „biografija samog Mate Lovraka i biografija slavnog romana Družba Pere Kvržice“ te koji „donosi cijelu sudbinu te knjige od trenutka kada je autor otvara iz paketa koji mu šalje izdavač do 1967. godine kada autor završava rukopis“ (urednik Zoran Maljković). Gradeći autobiografski diskurs ${ }^{2}$ elementima iz vlastita objavljenoga fikcionalnoga teksta, dječjega romana Družba Pere Kvržice iz 1933. godine, Mato Lovrak otkriva se kao žanrovski inovator u hrvatskoj književnosti jer nadilazi odrednice koje su u književnoj znanosti isprva bile ustvrđene kao elementarne u tvorbi autobiografije, ${ }^{3}$ čak i njezine posebne podvrste - književničke autobiografije. ${ }^{4}$ Kod Lovraka otkrivamo poseban oblik susretanja dvaju načela proizvodnje diskursa, načela fikcionalizacije i načela težnje za stvaranjem (privida) istinosnoga, provjerljivoga i stvarnosnoga teksta, koji su, prema Andrei Zlatar, karakteristični za autobiografske tekstove (1998: 5).

Naime, Lovrakov autobiografski roman Pero Kvržica među ljudima građen je intertekstualno, pri čemu taj predmetni tekst (tekst 2. stupnja) donosi čitatelju primjer svojevrsnoga metateksta u obliku (autoreferencijalnoga) narativa o nastanku i recepciji romana Družba Pere Kvržice (referentni, tekst 1. stupnja). Oba su stupnja neodvojiva od biografije samoga autora do te mjere da su pripovjedač predmetnoga, autobiografskoga teksta (u ovome slučaju neka vrsta heterodijegetičkoga i ekstradijegetičkoga pripovjedača, što je također različito od uobičajenoga autodijegetičkoga pripovjedača) i fikcionalni likovi iz referentnoga teksta dječjega

2 Pojam Mirne Velčić, koji dolazi kao rezultat odustajanja suvremenih teoretičara književnosti od identifikacije temeljnih svojstava forme ,autobiografije“ (upravo zbog njezinih nejedinstvenih formalnih obilježja). Prema De Manu autobiografija nije žanr ili modus nego figura čitanja ili razumijevanja koja se pojavljuje, u određenome stupnju, u svim tekstovima (Zlatar 1998: 8).

3 Philippe Lejeune (2000) autobiografiju je definirao s pomoću odnosa između čitatelja i autora i taj odnos u radu iz 1975. nazvao autobiografskim ugovorom. Temeljne su odrednice toga ugovora: pripovijedanje u prozi, osobni život kao tema, identičnost autora (ime predstavlja stvarnu osobu) i pripovjedača, položaj pripovjedača (identičnost pripovjedača i glavnoga lika) i retrospektivna perspektiva pripovjednoga teksta (Lejeune 2000: 202). Osobno ime autora, pripovjedača i protagonista obećava autentičnost svega zapisanoga, ali taj se ugovor može ponuditi čitatelju (drugomu partneru ugovora) na različite načine. Uporaba prvoga lica jednine nije dovoljna jer se ne razlikuje od fikcionalnoga pripovjedača koji pripovijeda u 1. licu, no sljedeće indicije smatra dovoljnima: a) odabir naslova, b) intenciju izrečenu na početku teksta i c) spominjanje vlastita imena u tekstu. Kasnije se posumnjalo u posvemašnju relevantnost tih indicija. I sam Lejeune, primjerice, 1977. napisao je studiju Autobiografija u trećem licu (usp. Eigler 2002, Lejeune 2000).

${ }^{4}$ U tzv. književničkoj autobiografiji općenitom se karakteru nacrta u svakoj autobiografiji pridružuje i shvaćanje samoga sebe kao autora te vlastiti komentar o ranije nastalim djelima. Sigurd Paul Scheichl taj oblik književničke autobiografije označava kao „metaknjiževnu funkciju“ (prema Eigler 2002). 
romana mjestimice predstavljeni na istoj pripovjednoj razini i kao aktanti od podjednake važnosti. Stoga Lovrakov predmetni tekst posve negira odvojeni odnos personalnoga autora/književnika i njegova djela, koji je bio predmet rasprava još od kraja 19. stoljeća sve do suvremenih teorija. Upravo suprotno, poistovjećivanje književnika i djela (ali nipošto u pozitivističkome smislu) određenim se postupcima u Lovrakovu pripovijedanju dovodi na razinu simboličke funkcije (djelo je ,živo“ i ima svoju ,biografiju“, djelo postaje metafora ,po kojoj se živi“, neodvojivo je od književnikova sebstva) ${ }^{5}$ produbljujući složeno pitanje tekstualnoga konstruiranja identiteta subjekta ${ }^{6}$ unutar autobiografskoga diskursa, i to osobito kada je njegov autor-književnik. Taj poseban odnos književnika i njegove autobiografije potvrđuje se i stavovima samih književnika, poput Antuna Šoljana ili Nikole Milićevića, koje prenosi Vinko Brešić u predgovoru knjizi Autobiografija hrvatskih pisaca (1997). Milićević pravom (auto)biografijom naziva duhovnu biografiju nekoga pisca, a nju čine - njegova djela. Međutim, Brešić postavlja pitanje kako razdvojiti vezu između stvarne i duhovne biografije, a da tako razdvojene ne postanu - fikcijom (1997: 22-23). U ovome se radu, pak, pitamo radi li se u književničkim autobiografijama (i ostalim oblicima književničkoga autobiografskoga diskursa) o praksama kojima sami književnici potkopavaju stavove o odvojenome odnosu biografije autora i njihovih djela. ${ }^{7}$ Praksa koju u tome smislu nalazimo u Lovrakovu autobiografskome

5 Govoreći o statusu autobiografskoga teksta tijekom povijesti njegova istraživanja, Friederike Eigler obrazlaže kako je došlo do shvaćanja da se u samome temelju autobiografskoga diskursa zapravo nalazi iskustvo subjekta kao ljudskoga bića, pozivajući se na studiju Jamesa Olneya Metaphors of Self (1972). Iz iste studije Eigler kao egzemplarno izdvaja mišljenje da sve autobiografije upućuju na ,jedan subjekt, jedan motiv iza svih ljudskih nastojanja na bilo kojem području: upravo iskustvo ljudskog bića“ (1972: 317, cit. u Eigler 2002). Za istraživanje identiteta subjekta u književničkoj autobiografiji važna je Olneyjeva teza po kojoj prizvati sjećanje, biti svjestan i povećavati svjesnost, stvoriti svoju metaforu, znači živjeti.

${ }^{6}$ Još je Mirna Velčić u knjizi Otisak priče iz 1991. problematizirala identitet subjekta kao temelj autobiografskoga teksta smatrajući da je taj identitet prividan, da se proizvodi u tekstu odnosno da je fiktivna, retorička konstrukcija, što je, prikazujući hrvatske studije o autobiografiji, istaknula A. Zlatar (1998: 10).

7 Ovaj rad predstavlja nastavak našega istraživanja toga problema započetoga člankom „Metalepsa i poigravanje funkcijama književnog teksta u humoreskama Bratoljuba Klaića“ (Kuvač-Levačić 2014). U autobiografskim humoreskama Klaić konstruira osobit autoironijski odmak od javne slike samoga sebe koji temelji na obratu i odmaku od uspostavljenih unutartekstualnih i izvantekstualnih odnosa, ostvaruje ga uključivanjem metalepse, potkopavanjem granice između fikcije i stvarnosti, književnoga i neknjiževnoga, metanarativnošću, autoreferencijalnošću, kao i samim ironiziranjem funkcija književnosti. Pitanjem tekstualnoga konstruiranja identiteta književnika koji piše autobiografski tekst bavili smo se i u radu „Metafore sebstva u autobiografskom diskursu Vesne Parun“ (Kuvač-Levačić 2016). U odnosu književnosti i zbilje koji sam žanr autobiografije, kao što je poznato, propituje na poseban način, Vesna Parun stvara odmak od pukoga dokumentarnoga prenošenja zbiljskih činjenica iz svojega života. To se odražava ne samo u negiranju kronološkoga niza ispripovijedanih događaja u korist kolažne i fragmentarne organizacije teksta, nego u postupku kojim autorica, što je osobito zanimljivo i zbog usporedbe s Lovrakovim tekstom posebno važno, negira odnos „metafora kao sredstvo književnosti“ pretvarajući ga u odnos „književnost kao metafora vlastita sebstva“. 
romanu stvaranje je tzv. „biografije djela“. Da bismo razumjeli kako Lovrakov predmetni tekst tim postupkom potkopava spomenutu odvojenost odnosa pisac djelo, važno je najprije upoznati se s osobitostima same književničke autobiografije kao posebne vrste, o čemu je pisala Sanja Grakalić-Plenković (2014), ali i s postupkom autobiografizma u tekstovima koji se ne klasificiraju kao autobiografije, kako je to definirala Magdalena Medarić (1993).

Naime, autobiografski tekstovi gotovo se uvijek naručuju od književnika i društveno priznatih osoba koji potom diskurzivno oblikuju osobni model kojim se žele predstaviti javnosti, ali istodobno i ovjeriti unutar socijalne, političke i kulturne recepcije (Sablić Tomić 2002: 16). Baveći se autobiografijom javnih osoba, S. Grakalić-Plenković istaknula je rođenje, školovanje, službu, trenutačno zaposlenje i osvrt na objavljena i napisana djela kao tematske krugove koji se mogu nazvati nezaobilaznima u poimanju javne autobiografije, dok su razlike među piscima primjetne na razini kompozicije (2014: 105-106). U Lovrakovu predmetnome tekstu takvih elemenata nema, no u njemu ipak dominira autobiografizam.

Magdalena Medarić autobiografizmom naziva stilski markirani književni postupak koji predstavlja refleks žanra autobiografije, a javlja se u tekstovima koji sami po sebi nisu mišljeni ni recipirani kao autobiografije (1993: 46). Znanstvenica ne propušta spomenuti i autobiografske tekstove u kojima autor uvodi sebe $\mathrm{u}$ liku pisca pa tematizira vlastiti književni postupak, raspravlja o umjetnosti općenito. Za nju će biti zanimljivi takvi slučajevi (a češći su što se povijesno više približavamo postavangardi ili postmodernizmu) u kojima je autor konkretizirao sebe, umjetnika, i kao empirijsku osobu ili konkretnoga umjetnika u vremenu i prostoru. Teško je razlučiti te dvije umjetnikove sfere, javnu i intimnu, jer se one preklapaju (Medarić 1993: 54-55). Upravo tim se postupkom služi i Lovrak i na razmeđi javne i intimne, fikcionalne i stvarnosne sfere gradi, odnosno predstavlja svoj književnički subjekt.

$\mathrm{Za}$ istraživanje identiteta subjekta $\mathrm{u}$ književničkoj autobiografiji poticajne su teze znanstvenika Jamesa Olneya koji u svojoj knjizi Metaphors of Self: The Meaning of Autobiography (1972) među ostalim navodi da je svaka pojedinačna autobiografija izricanje cjeline ljudskoga bića, čin samotvorbe (act of selfrealization). Ta se simbolička cjelina - kako netko ostvaruje sebe - stvara $\mathrm{u}$ metaforama, a zatim u čitateljevu iskustvu toga „idealnoga bića“ i ostvarenoga „sebe“, što ponekad nazivamo autobiografskim činom, ponekad poezijom, ali je uvijek riječ o umjetnosti. Olney čin nastajanja autobiografije uspoređuje s čovjekovim nastojanjem da se ostvari kao cjelina, u smislu konstruiranja cjelokupnoga ljudskoga iskustva koje Olney naziva „Simboličkim Čovjekom“, da se vrati svojoj prvobitnoj cjelovitosti (koja je u mitskoj svijesti izgubljena izgonom iz Edena), a to je u sadašnjemu ljudskome stanju moguće izvesti samo na sintetičkoj ili simboličkoj razini (usp. Olney 1972: 318). Tako je svaki ostvaraj pojedinačnoga 
ljudskoga iskustva u nekome autobiografskome tekstu zapravo vlastita autorova metafora za Čovjeka (Olney 1972: 321).

\section{Odnos pripovjedača, autora i glavnoga lika u romanu Pero Kvržica među ljudima}

Pratimo li Lejeuneovu definiciju autobiografije (2000: 202), vidimo da Lovrakov autobiografski roman tematizira autorov osobni život i povijesni razvoj njegove osobnosti, ali isključivo u onome dijelu koji je primarno povezan s razdobljem objavljivanja i recepcije Družbe Pere Kvržice, premda uz neke faktografske nepreciznosti (npr. iako je dječji roman prvi puta objavljen 1933. godine, u predmetnome romanu navodi se godina 1930.). ${ }^{8}$ To se sve vremenski podudara s autorovim obavljanjem učiteljskoga posla u (zapadnoslavonskome) selu između dvaju svjetskih ratova, njegovim životom tijekom Drugoga svjetskoga rata i nakon njega: „Događaji, ovdje opisani, započeli su u Velikom Selu koje se nalazi u jednom dijelu Hrvatske, u krajevima između Save i Drave. Zbilo se to nekoliko godina iza Prvog svjetskog rata, u seoskoj školi“ (Lovrak 2014: 5). Ovdje valja spomenuti da su toponim Velikoga Sela (uz druge elemente o kojima će riječi biti nešto kasnije u radu) i imena dječjih likova intertekstualni s obzirom na podudarnost s imenima likova i mjestom radnje u Lovrakovim dječjim romanima Družba Pere Kvržice i Vlak u snijegu (roman je objavljen pod naslovom Deca Velikog Sela u Beogradu 1933. godine, a 2. izd. u Zagrebu 1946. pod naslovom Vlak u snijegu: djeca Velikog Sela, pripovijest za djecu) te se javljaju na samome početku teksta kao jasan signal čitatelju.

$\mathrm{U}$ predmetnome je tekstu uspostavljen odnos istovjetnosti glavnoga lika i autora, ali ne uz pomoć autodijegetičkoga pripovjedača, nego pripovijedanjem u 3. licu (svojevrsni „pseudoheterodijegetički“ pripovjedač, jer govoreći o drugim, ponajprije fikcionalnim likovima svojega dječjega romana, on zapravo govori i o sebi slično funkciji autodijegetičkoga pripovjedača). Postupak pripovijedanja u 3. licu i Lejeune zamjećuje i u autobiografijama drugih pisaca, čak i u starijim književnopovijesnim razdobljima, te ga tumači različitim uzrocima i prepoznaje njegove različite učinke. Govor o sebi u 3. licu može implicirati golemi ponos ili poniznost pri čemu se u obama slučajevima autobiografski pripovjedač odnosi prema liku koji je autor nekada bio, a koji sada predstavlja, pripovijedajući dakle $\mathrm{s}$ vremenskim odmakom i uvodeći u svoju priču transcendenciju s kojom se poistovjećuje. Učinak toga postupka može biti dojam slučajnosti, podvajanja ili

${ }_{8}$ Opisan je događaj kada učitelj pisac u malome provincijskome poštanskome uredu prima autorske primjerke tiskanoga romana Družba Pere Kvržice: Na službenoj tiskanici učitelj zapisuje: „Veliko Selo, 18. studenoga 1930. ..." (Lovrak 2014: 15). 
ironijske distance (usp. Lejeune 2000: 205), što se u Lovrakovu tekstu izmjenjuje. Iz sljedećega primjera vidimo učinak ponosa i podvajanja: „Putuje učitelj pisac vlakom u Zagreb i, premda mu srce igra od radosti, budući da ide ususret raznim izvanrednim događajima u svom životu, ipak se u vagonu čini osamljen“ (Lovrak 2014: 29).

Ovdje možemo spomenuti i dimenziju očitovanja pripovjedača s obzirom na odnos prema čitatelju (tzv. kontakt) Susan Sniader Larsen prema kojoj pripovjedač u 3. licu uživa autoritet povjesničara (1981, navedeno prema Biti 2000: 440), što Lovraku ipak nije primarna namjera, s obzirom na činjenicu da mu faktografska preciznost i nije najvažnija.

O identitetu Lovrakova glavnoga lika u Peri Kvržici među ljudima (predmetni tekst) doznajemo iz višestrukoga naglašavanja odnosa između učitelja Marka Matića - fikcionalnoga lika, predstavljena kao pisca romana Družba Pere Kvržice (referentni tekst, u kojemu učitelj nije imenovan) (Lovrak 2014: 31):

Učitelj pisac Marko Matić dolazi ovamo i po stoti put, pa još uvijek uzbuđen koraca preko Zrinjevca kao da je u Zagrebu po prvi put. Danas pogotovo jer očekuje susret s knjigom o Peri Kvržici. [...] Dovoljno je čovjeku sa sela doživjeti Zagreb pa da se posve preobrazi, a doći u njega i očekivati sastanak sa svojom knjigom, to već prelazi granice mogućeg.

Referentni je tekst, dakle, a ne autodijegetički pripovjedač ili ime glavnoga lika u ovome romanu, spona između ranije spomenutih načela fikcionalizacije $i$ težnje za ostvarivanjem (privida) stvarnosnoga, a time i signal po kojemu tekst prepoznajemo kao autobiografski. Kod Lovraka vidimo, dakle, formalni odmak od onoga što navodi, primjerice, Zlatar kada definira autobiografski roman ponajprije oznakom autobiografske forme pripovijedanja (ja-pripovijedanje), čak i bez obzira na to je li u tim tekstovima riječ o stvarnome autobiografskome sadržaju. Nadalje smatra da se oznaka „autobiografski roman“ odnosi čak i na tekstove u kojima je autobiografski ugovor (identitet autora, pripovjedača i lika) tek simuliran, a ne ostvaren (Zlatar 1998: 99). U Peri Kvržici među ljudima, naprotiv, očituje se izrazita autorova namjera da čitatelj doživi tu ostvarenost i poistovjećenost, i to ne samo glavnoga lika i autora, nego i glavnih likova obaju romana (predmetnoga autobiografskoga i referentnoga - dječjega): „Sav je u vrućici kao njegov Pero u knjizi“"(Lovrak 2014: 33).

Autorova intencija s obzirom na odnos prema faktografskoj vjerodostojnosti priče (za koju vidimo da se nastoji ostvariti, ali ipak ne kao potpuna preslika, već uz autorove intervencije i nadopisivanja stvarnosti), upravo potvrđuje tezu o njegovoj nakani da javnu predodžbu svoje osobe poveže s djelom do te mjere da njegova vlastita biografija postaje metatekstom, „biografijom“ samoga djela. I 
više od toga. Lovrakovi biografski podatci realiziraju se kao manje važni, dok je u prvome planu čin stvaranja, pisanja (njegova najpoznatijega) dječjega romana, ali i stvaranje novoga književnoga teksta o tekstu, o činu književnoga stvaranja, kao i svim posljedicama koje je taj čin prouzročio u stvarnome svijetu u kojemu je živio Mato Lovrak.

\section{Književnikov autobiografski roman kao biografija djela}

U kontekstu koji stvara autobiografski tekst uključivanjem faktografskih čimbenika, ostvaruje se poseban učinak oživljavanja fikcionalnih likova referentnoga teksta u najvećoj mjeri dijalozima između učitelja pisca i likova njegova romana (Lovrak 2014: 32):

Učitelju piscu se žuri. Uskoro će preko Jelačićevog trga pa u Dugu ulicu do malih knjižara, kadli odjednom kao da ga netko zovnu, kao da ga uhvatio za ruku i nogavicu od hlača. I čuje on glasove. Muške i ženske. Dječje. „A mi?! Samo tako prolazite pokraj nas?! Zar se nećete s nama porukovati?!“ [...] Stade on na pločniku kao gromom ošinut. I predobro pozna ove dječje glasove pa se ogleda. U izlogu knjižare na Zrinjevcu mnogo je knjiga zelene boje, ali među njima i njegova „Družba Pere Kvržice“.

I dalje (91 i ostatak dijaloga na str. 92, 93 i 94):

Rukom prijeđe preko jednog složenog reda [knjiga] i odjednom osjeti nešto neobično. Ruke! Uhvatile ga one i zaustavile. Krikne pisac u tami: - Tko je to? - Mi. Družba Pere Kvržice. Odlazite li od nas sasvim ili se vraćate prekosutra? [...]

Odnosom prema fikcionalnim likovima referentnoga teksta, koji su u svijesti glavnoga lika - pisca u predmetnome tekstu oživljeni, iskazuje se jezgra piščeve osobnosti i njegova različitost od svijeta koji ga okružuje, što i jest jedan od ciljeva svake autobiografije, a osobito književničke (Lovrak 2014: 38):

Drugi čovjek stajao bi ovdje s uvjerenjem da to nisu živa bića već papir i na njemu opisani izmišljeni likovi djece i događaji s njima..., a on nikako, ama baš nikako da se otrese tog nemogućeg u sebi! [...] On želi, vruće želi, odvesti ih u Veliko Selo, k sebi, kući....

Također (Lovrak 2014: 34):

Svog „Kvržicu“ na policama knjižare učitelj doživljuje bolno. Djeci, naročito seoskoj, ondje je tijesno, zagušljivo, tjeskobno. On bi ih najradije oslobodio, ali jedino tako da kupi sve knjige, što ne može jer ih je najmanje deset primjeraka.

i dalje (Lovrak 2014: 71):

Onaj tko ima sreću da mu učitelj posudi knjigu, sakrije je na njedra pod košulju. [...] Družbi između tvrdih korica na tom mjestu neobično. Ta, čuju burno udaranje srca njihovog poštovatelja, no ujedno im je ganutljivo do suza [...] 
Dječji likovi u predmetnome tekstu (kojemu autobiografski modus pojačava „stvarnosna“ obilježja, pa se i oni u svijesti čitatelja percipiraju kao „stvarna djeca“) ponekad se izravno referiraju na likove u referentnome upućujući na Lovrakovu motivaciju djecom iz vlastita životnoga okružja pri karakterizaciji likova referentnoga teksta. Postupak je to koji također upućuje na težnju za ostvarivanjem autobiografskoga diskursa kao biografije djela, što u predmetnome tekstu polučuje učinak igre i humora, čak i autoironije (Lovrak 2014: 77):

Dječje ruke šire grančice grma i kroza nj proviri najmanji, drag učiteljev učenik. Milo dijete!

- Oho! Jedan od glavnih lica iz Družbe Pere Kvržice! - kaže mlinar.

- Ja nisam dječak iz knjige. Mene mama ne tuče radi skitnje [...]

- Zar ti ne želiš biti ono milo dijete? - mlinar će dječaku, a on ne odgovara. Mlinar navaljuje daljnjim pitanjima: - Ti bi u knjizi bio onaj koji u koritu veslaš i slučajno pokrećeš mlin. Zar te to ne privlači?

Lik Miloga djeteta posebno je dokumentiran u predmetnome tekstu zbog sudbine stvarnoga dječaka koji je piscu poslužio kao model. O toj ćemo sudbini doznati na kraju romana, u situaciji kada pisca pozovu u selo gdje je službovao dok je pisao Družbu Pere Kvržice (Lovrak 2014: 273):

Samo ne vidje čovjeka, koji mu je poslužio kao lik za Milo dijete [...] Umjesto njega došao na proslavu njegov otac, starac sijede kose da ispriča sina što ne može danas u školu doći... Otjerali mu dijete kao mladića aktivista u koncentracijski logor gdje mu mladi život oduzeše [...]

Lovrakov je autobiografski roman i izrazito socijalno i politički angažiran što pratimo tematiziranjem odnosa društva prema knjizi i književnosti, grada i sela, bogatih i siromašnih, politički suprotstavljenih itd. Sve su te teme obilato zastupljene i u Lovrakovu korpusu dječje književnosti. No, posebnost je ovoga romana to što se one donose kao neupravni govor u spomenutim dijalozima između pisca i njegovih likova (Lovrak 2014: 56):

Na stolu, malo dalje od piščevog ležaja nalazi se njegova knjiga Družba. Tuži mu se Pero. S njim i drugi članovi. Mučan im je, kažu, život u knjižarama velikoga grada. Dolaze majke građanke kupiti djeci svojoj knjigu. Knjižar ponudi i „Družbu Pere Kvržice“, ali one i ne zavire u sadržaj. Odbacuju knjigu koja piše o „kumekima“, bolje reći o malim seljačićima $[\ldots]$

Iz takvih se dijaloga doznaje ponešto i o popularnim žanrovima dječje književnosti u doba izlaska Družbe Pere Kvržice, pa i o prvotnim problemima u recepciji romana (Lovrak 2014: 56-57):

Neugodno, vrlo neugodno se osjećaju u društvu kraljevića i vila... Učitelj ih razumije i tješi jadnike iz svoje pripovijesti kako treba proći dosta vremena, pa će se kupci knjiga zanimati i za pripovijesti koje nisu samo bajke nego imaju istinit sadržaj s glavnim junacima koji su prava, živa djeca, bilo sa sela ili iz grada [...] 
Tako se dijalozi pisca i njegovih likova pretvaraju u metatekstualni okvir u kojemu se nazire Lovrakov odnos prema tradiciji hrvatske i svjetske dječje književnosti i vlastitim uzorima u doba nastanka Družbe, što svjedoči o inventivnosti Lovrakova autobiografskoga diskursa $u$ formi romana, pogotovo u onome aspektu u kojemu prepoznajemo biografiju djela, a koji se osim dijalogizmom, ostvaruje i intertekstualnom igrom (Lovrak 2014: 57):

Na hrpi knjiga u knjižari s njima zajedno još je netko! Njihov dobar susjed, šegrt po imenu Hlapić. I još jedan, doduše gradski, ali zgodan dječak s kojim bi se oni mogli složiti. To je Emil. Sakupio on djecu da s njihovom pomoći, kao nekakvi detektivi, uhvate lopova, tata... Učitelj pisac obradovao se kad je saznao da njegova Družba ipak u knjižari nije osamljena, možda i prezrena. Preporuči on Peri i njegovoj družbi da se sprijatelje sa šegrtom Hlapićem te s Emilom i njegovim detektivima. Bit će im u životu lakše u društvu s drugom čestitom djecom, njima sličnom, jer družbu i dalje čekaju borbe, vjerojatno i teže od onih oko podizanja seoskog mlina vodenice.

Ali i ne samo to. Kraj navedenoga citata podcrtava istovjetan odnos između djela i autora potvrđujući tezu o djelima kao duhovnoj biografiji autora. Središnji je postupak toga poistovjećivanja metalepsa ${ }^{9}$ autora, kauzalna relacija koja ujedinjuje stvaratelja nekoga umjetničkoga prikaza sa samim prikazom (Genette 2006: 11) u kojoj se piščeva borba za društveno prihvaćanje ideologije njegova dječjega romana prikazuje kao borba samih likova romana (Lovrak 2014: 58):

Poslije dovršenog mlina nastaje bitka za priznanje i prihvaćanje njihovih misli o slozi i požrtvovanju. Još veću i težu borbu imat će oko nastojanja da se prizna i poštuje vrijednost i veličina njihovog rada koji oni ne poduzeše samo za se, nego i za selo, za sve ljude...

Svjedočimo trostrukomu poistovjećivanju - javne ličnosti Mate Lovraka s likom učitelja Matića u predmetnome, i s likovima djece, ponajprije Pere Kvržice u referentnome tekstu. No vrhunac oživljavanja fikcionalnih likova referentnoga teksta nalazimo u situacijama kada oni nastupaju kao aktanti ravnopravni likovima u predmetnome tekstu (u prvome redu samomu protagonistu). Često se likovi pojavljuju kao aktanti u trenutcima kada treba reagirati onako kako bi sam pisac zapravo želio (ili je želio onda kad su se neke od tih zgoda događale u stvarnome životu). To se može interpretirati na način da pisac, radi slike koju želi o sebi ostvariti, ne može liku koji ga predstavlja „,dopustiti“ neprimjereno ponašanje, međutim ovdje naglasak stavljamo na sam postupak prekoračenja. U tome smislu

9 Metalepsa je u naratologiji definirana kao prekoračenje pripovjedne razine te stoga kao postupak pogodan za iskazivanje prekoračenja granice između dvaju svjetova - književnoga i izvanknjiževnoga, onoga o kojemu pričamo i onoga u kojemu pričamo, na primjer kazališne pozornice i publike. Kao narativni postupak uvodi ga i objašnjava G. Genette u Figures III iz 1972., a do kraja razrađuje u knjizi Métalepse. De la figure à la fiction iz 2004. (Bagić 2012: 195). 
ističe se primjer kada učitelj pisac dobiva uvredljivo pismo zbog kojega upada u stanje koje predstavlja svojevrsni otklon od stvarnosti i koje, kao takvo, postaje kulisom metaleptičkoga prekoračenja likova iz referentnoga teksta u predmetni (Lovrak 2014: 85-86):

Kad je s takvim duševnim stanjem povezana i neka želja, nikakvo čudo što Pero upravo ovog časa uzima sa stola pismo koje je učitelja danas strašno ogorčilo. Dječak čita družbi pismo naglas: [...]. Pero je pismo pročitao, a uzbuđeni članovi družbe podignu viku. Oni misle da je ovaj slučaj vrijedan da ga oni uzmu u svoje ruke. Smatraju čak zapuštene mlinove manjim zlom od ovako pakosnih jezika... [...]. Družba viče, bjesni, škripa zubima. Uzimaju dječaci batine u ruke. Prenagljuju se... Pero krikne spasonosnu riječ „kvržica“ i sve se smiri. Opet je seoska večernja tišina u školskoj zgradi $[\ldots]$.

I dalje (87):

Pero iz knjige pita, a pisac mu odgovara. Sazna družba što je učitelj učinio. [...] Ovako pisac učitelj kao da se ispričava družbi jer on članove najbolje pozna. On ih je opisao. Učitelj kao da im pravo ni u oči ne smije pogledati. Oni na prostaka napadača podigoše batine, a on mu pismo piše. Kakve li razlike!

Sličan je primjer kada mladi student iz Velikog Sela napiše lošu i politički motiviranu kritiku romana, što će komentirati lik djevojčice Marije iz referentnoga romana (124):

[...] ali se tad javi Marija, tihim glasom djevojčice, ali ipak oštro izgovorenim:

- Bog mu neće dati sreće!

I opet družba zanijemi. Nisu očekivali ovakvu kletvu kakva se u seoskim kućama običava izgovarati u velikom ogorčenju i jadu.

Ostvarivanje autobiografskoga predmetnoga teksta kao biografije djela očituje se u nastojanju da se osim odnosa autora kao tvorca književnoga djela (referentnoga teksta), u istome tome predmetnome tekstu na razini prenesenoga značenja uspostavi i reverzibilan odnos književnoga djela kao tvorca svojega autora. U tome je smislu indikativno da se u predmetnome romanu izrijekom navodi kako su razgovori s njegovim likovima pomogli učitelju piscu da nadiđe spisateljsku krizu u trenutcima suočavanja s politikantskom kritikom te da nastavi stvaranje novoga romana (Lovrak 2014: 126-127):

Nakon više takvih razgovora između učitelja i njegove družbe, uspije njemu othrvati se duševnim mukama poslije kritike, čak u tolikoj mjeri da je dobio volju uzeti u ruke novo svoje započeto književno djelo. [...] Učitelj-pisac riješio se pritiska kao bolesnik bolesti i započe pisati daljnje poglavlje svog novog djela „Neprijatelj broj 1“.

Nadilazi se pritom tradicionalni komunikacijski lanac između autora koji s pomoću djela komunicira s čitateljem, pri čemu je djelo svojevrstan objekt (pisac stvara djelo, djelo djeluje na čitatelja, usp. Lešić 2008: 53), jer kod Lovraka sâmo 
djelo (referentni tekst) komunicira $\mathrm{s}$ autorom i drugim književnim tekstovima podcrtavajući ideju da ono kao takvo, oživotvoreno u stvarnosti, djeluje na sudbinu samoga pisca postajući subjektom. Svojim ga utjecajem čak i nadilazi, stoga su djelo $\mathrm{i}$ autor, pa onda i biografija djela $\mathrm{i}$ autorova (auto)biografija neraskidivo povezane. No, da djelo, kao i čovjek, ima svoju biografiju, Lovrak potvrđuje i time što mjestimice ipak inzistira na prikazu potpune autonomnosti sudbine djela među čitateljima, tematiziranjem neznanja protagonista pisca o dosezima recepcije vlastita teksta (Lovrak 2014: 69):

Šteta je i to žale, vrlo žale djeca Družbe, što njihov učitelj pisac ne zna za svaki ovakav njihov poseban uspjeh. Piscu ljudi radije javljaju neugodne, nemile vijesti u vezi s knjigom, a malo, vrlo malo, stiže mu dobrih glasova. Pero Kvržica i među neprijateljima stekne pokojeg pristašu. Knjiga o družbi, istina, pomalo i sporo, ali ipak neke ljude pridobije za naprednu, bolju, ljepšu životnu misao [...]

Posebno je upečatljiv dio romana koji tematizira tu sudbinu djela u razdoblju Drugoga svjetskoga rata kada se Družba Pere Kvržice nađe na popisu zabranjenih knjiga u Nezavisnoj Državi Hrvatskoj (NDH-u) (Lovrak 2014: 163):

Eto, njegova Družba je na popisu zabranjenih knjiga zajedno s djelima svjetskih velikana... Kako će se vladati seoski njegovi dječaci iz Družbe u društvu poznatih likova romana, drama i tragedija?! [...] Takve mališane strpati u logor zajedno s Anom Karenjinom! Ograditi bodljikavom žicom malog seljačkog dječaka Peru zajedno s njezinim mužem, vlastelinom Karenjinom! [...] Kako će se osjećati grofica Karenjina zajedno u društvu sa seoskom djecom iza žice logora?!

U ovome se dijelu sudbina djela poistovjećuje sa sudbinom svih progonjenih ljudi, odraslih i djece u totalitarnome sustavu; ona, dakle, postaje metaforom općeljudskoga iskustva (Lovrak 2014: 167):

Otkako je družba seoske djece na indeksu, oni više ne žive. Ne misle, ne osjećaju. Ne govore, ne kreću se, ne miču. Kruti su, ledeni, mrtvi, pa ipak hoće odavde u onu rupu tamnog potkrovlja. [...] Tvrde korice knjiga su hladne, ledene, onako, gdje krv više ne kola, gdje srce ne bije. [...] Družba mrtve djece u naručaju učitelja pisca [...]

Metafora „mrtvoga djela“, zabranjena i izbačena iz svih školskih knjižnica u doba Drugoga svjetskoga rata i NDH-a, tematizira nemogućnost odvajanja djela od njegovih čitatelja, baš kao što se ni autor ne može odvojiti od toga dvojstva. U toj se metafori možda najočitije predstavlja ideja biografije djela kao autorove vlastite biografije (Lovrak 2014: 181):

Ne dira više beživotnu knjigu. Ona je mračan prostor bez ikakva živa stvora. Ne leti više ptica. Ne pliva riba. Ne teče voda rijekom. Ne gomilaju se oblaci. Ne sijevaju munje. Ne pucaju gromovi. Ne pljušti kiša... Prostornost knjige je posve prazna, ogoljela, bez ikakvih stvari. [...] Knjiga ova sva je mrtav predmet u raspadanju! [...] 
Kada se, krajem rata, na zahtjev skupine učitelja, Lovrakov roman skinuo s indeksa zabranjenih knjiga, djelo je nastavilo svoj život i u životu učitelja pisca. Družba s piscem popravlja bombardiranu piščevu kuću pa dolazi do preklapanja tematskih, ali i idejnih sekvencija referentnoga i predmetnoga teksta (u motivu kolektivne obnove prostora) (Lovrak 2014: 204-205):

U osam sati sretno stiže družba Pere Kvržice na ruševinu kuće i odmah se prihvate posla. Vidi se da su sada na svom mjestu, ondje gdje se mogu razmahati, i živjeti. Nekad na seoskom zapuštenom mlinu, sada na srušenoj kući. Zasukaju djeca rukave, pljuckaju mali radnici u šake, i nadižu grede [...]

Pisac i njegovi likovi i u ovoj su situaciji prikazani na istoj aktantskoj razini (Lovrak 2014: 203):

Učitelj pisac sjedi na gredi, teško diše i džepnom maramicom briše znoj, a djeca družbe raštrkala se kojekuda. Pero se vraća iz porušene kuće ljutit, bijesan. Tuži se učitelju piscu na ljude. [...] Peru, Šilu i sve druge članove obuzimlje srdžba. [...] I upravo tog časa dolazi starac, ali poznat čovjek, susjed. [...] Moli pisca da mu proda jednu gredu.

Lovrakov autobiografski diskurs nikada ne gubi vezu s dokumentarnim. Tematiziraju se povremeno reakcije okoline na piščevu osobnost, što često rezultira autoironijskim učinkom, npr. reakcija njegove žene (Lovrak 2014: 224):

- Zar si opet vidio družbu Pere Kvržice?!

$-\mathrm{Da}$.

- I vidio si ih opet jedino ti! [...] Zaista, i radi tvojih priviđenja krajnje je vrijeme da se podvrgneš operaciji i drugom temeljitom liječenju!

U predmetnome se tekstu također tematizira i omalovažavajući odnos prema dječjoj književnosti koji se nastavio i nakon Drugoga svjetskog rata, unatoč proklamiranju povlaštena položaja Lovrakova djela. Očituje se to u situaciji kada pisac otkriva da u izlogu knjižare koja je nakon rata željela predstaviti u ratu zabranjene knjige, nema njegove Družbe. Osim socijalnoga, naglašen je i kulturni angažman učitelja pisca (Lovrak 2014: 235):

On neće dopustiti da njegovo književno djelo o radnoj skupini djece bude sada potisnuto, omalovažavano. Pronaći će on uzroke nemiloj pojavi kakvu je danas našao u izlogu nove knjižare. „Družba Pere Kvržice“ bila je u ratu na popisu zabranjenih knjiga, a danas netko iz knjižare nije vratio nepravedno joj oduzeta časna prava. Pisac „Kvržice“ drži da je to učinio čovjek, jedan od onih koji ne razumije pisca za djecu. [...] Povest će pisac borbu protiv potcjenjivanja književnosti za djecu. Za nju će on svim silama nastojati ishoditi ravnopravnost s književnim stvaralaštvom za odrasle čitatelje $[\ldots]$

U oblikovanju identiteta subjekta u Lovrakovu autobiografskome romanu prisutna je, dakle, i dokumentarnost koja posebno dolazi do izražaja u dijelu romana koji obrađuje sudbinu djela i njegova autora nakon Drugoga svjetskoga rata kada autor postaje poznati i priznati dječji pisac, član Društva književnika. Kao 
takav, uspijeva utjecati na društvenu percepciju dječje književnosti, ali neprestano ostaje svjestan da se „kritizerstvo“, unatoč promjeni društvenoga uređenja, neće promijeniti (Lovrak 2014: 242):

Borbi, natezanja, pravde i nepravde među umjetnicima neće nestati ni danas, u novim društvenim odnosima. [...] Tako je bilo nekad, tako je i sada i tako će biti i ubuduće, dok god umjetničko djelo ne ocjenjuju računski neki strojevi već ljudi od krvi i mesa sa svim svojim ljudskim slabostima...

Učitelj pisac i dalje se susreće s negativnim, uglavnom anonimnim kritikama, koje shvaća vrlo osobno, dok njegov roman zadobiva pozornost novih generacija mladih čitatelja i doživljava svoje prve prijevode i kazališne adaptacije (Lovrak 2014: 251):

Upoznavaju ga djeca novog naraštaja. Ona koja su se u ratu rodila i odrasla [...] Pero sa svojom družbom otputuje na dalek put. Prijeđe na čamcu rijeku, granicu između Hrvatske i Slovenije i stigne sretno u Ljubljanu. Nije se družba u susjednu našu republiku odskitala, nego su je Slovenci pozvali u goste. Zapravo se radi o posve drugoj stvari. Knjiga „Družba Pere Kvržice“ izišla je ondje na slovenskom jeziku.

Također, dalje (255-256):

Igrokaz „Družba Pere Kvržice“ izvode i na moru. U velikom lučkom gradu, na pozornici nove kuće, nebodera. [...] Još veće glumačko umijeće pokazuju isti mali glumci u Zagrebu, na pozornici Dramskog kazališta, kamo su pozvani na gostovanje.

U predmetnome se tekstu promatra i ostarjela učitelja pisca u trenutcima stvaranja i ti su elementi također vrlo važni u razmatranju konstrukcije identiteta subjekta u književničkome autobiografskome tekstu, kao i svi oni elementi koji tematiziraju položaj književnika u društvenoj i književnoj zajednici, a što sve nalazimo u ovome Lovrakovu autobiografskome romanu (Lovrak 2014: 267):

Umirovljenik pisac radi mnogo. Dopodne od osam do dvanaest. Puna četiri sata! Odlaže pero i odlazi od kuće prije reda jedino onda kad za pisaćim stolom osjeti posebno težak umor uz drhtavicu u laktima i koljenima od prenapetih živaca. Tad sjeda na tramvaj i odveze se u okolicu grada, daleko, čak do obližnjeg sela. [...] Pisac u šali naziva tu svoju hitnju „bijegom“ od kuće, zapravo od stola za pisanje.

U romanu se iz perspektive protagonista dokumentira i sukob između starijih i mladih pisaca dječje književnosti (Lovrak 2014: 268):

Te godine izašla je knjiga za djecu, koju je napisao također jedan mladi književnik. Veliki grad nagradi ga za to djelo većom svotom novca, što umirovljeni učitelj pisac nije nikada primio ni za jedno od svojih djela.

Strogi mladi ocjenjivači mu priznaju da su njegova djela iz seoskog života vrlo dobra. [...] ali svi odreda proglašuju mu knjige sa sadržajima iz gradskog života kao posve neuspjele. Taj život, pišu oni u književnom časopisu mladih, bolje će opisivati njihov drug. 
Subjektivnost, ponegdje i jednostranost Lovrakova iskaza u predmetnome je tekstu kvaliteta, a ne nedostatak upravo zato što je autobiografski diskurs prije svega otisak autorova osobnoga iskustva i doživljaja, odnosno autokonstrukt subjekta. Njega čine i izrazito ideološki obojeni segmenti teksta (Lovrak 2014: 274):

Zatreba li negdje u mjestu, na njivama i livadama, u šumi ili bilo gdje da se nešto hitno uradi za zajedničko dobro čitavog sela, ne treba mještane silom tjerati ni zapovijedati im da idu na taj posao jer oni dobrovoljno uzimaju lopate i motike u ruke i odlaze na rad... A postoji li parni mlin usred sela? Da, on je tamo. U njemu se život melje, ali to je sada zajednička imovina sela. [...] I sada tvornica radi, samo ona je narodno dobro kojim upravlja radnički savjet...

Ipak, pisac ne zatvara oči pred činjenicom da se društvo ne razvija prema proklamiranim idealima, čega je simbol srušena vodenica u piščevu rodnome kraju koji je posjetio kao starac. Simbol iz referentnoga teksta prenosi se u predmetni tekst, no sada u suprotnome značenju (Lovrak 2014: 281):

Ne razumije brat iz grada jer tu nema vodenice, potoka, ni jezerca ispod točka. Ničega nema što bi podsjećalo na nekadašnji mlin! Srušen je radi toga što su zemlju ovdje morali tako urediti da uzbujali potok ne poplavljuje šumu i livade. Mlin je srušen. Seljaci zadrugari razvukoše svu građu. I točak raskomadaše na stupove, stupiće, daske i daščice, a srce mlina, onaj kamen što melje žitna zrna, uze seljak, sadašnji vlasnik njihovog negdašnjeg posjeda, njihove rodne kuće. On je za mlinski kamen nabavio električni stroj koji ga pokreće za meljavu sebi, susjedima, zadrugarima bivše vodenice uz manju, a drugima iz sela uz veću naplatu [...]

Vratimo li se Olneyjevoj tezi o pojedinačnome ostvaraju ljudskoga iskustva $\mathrm{u}$ nekome autobiografskome tekstu kao vlastitoj metafori svakoga pojedinoga autora za opće Čovjekovo iskustvo, jasno je da glavno iskustvo u književničkome autobiografskome tekstu, poput Lovrakova, predstavlja piščevo iskustvo, iskustvo tvorca književnoga djela. Nije ni čudo, stoga, što u tome smislu Lovrakov predmetni tekst, autobiografski roman Pero Kvržica među ljudima, počiva na postupku koji smo opisali kao stvaranje biografije djela i kao temelj autorova konstrukta „sebe“. Biografija djela, a ne biografija Lovrakova građanskoga života (što je postupak uobičajen $u$ autobiografijama), predstavlja se kao njegova primarna identitetska odrednica, s bitnim utjecajem na sve glavne strukturne odrednice predmetnoga teksta. Identitet subjekta u ovome je tekstu konstruiran dokumentarno i fikcionalno, a elementi koje smo istražili pokazuju da Lovrakov autobiografski diskurs zbog svoje intertekstualnosti i metatekstualnosti, među ostalim, posjeduje karakteristike otvorenoga znaka. Granice teksta brišu se prema drugim tekstovima, a čak je i stvarnost predočena u sklopu svojevrsne „otvorene ontologije“"10 kao „mogući“

${ }^{10}$ Jean-Marie Schaefferov pojam otvorene ontologije: „ako se stvarnost ne ograničava na stvarni svijet, već sadrži moguće svjetove, onda i sami fikcionalni svjetovi dobivaju vlastito postojanje - barem ukoliko uspijemo pokazati da je status fikcionalnih svjetova isti kao i status mogućih" (navedeno prema Mirčev 2008). 
svijet $u$ kojemu je manje važna faktografska preciznost. Otvoreni se znak osim strukturnim elementima i funkcijama, interpretativno poigrava i svim ostalim elementima književnoga komunikacijskoga lanca: autorom, tekstom (tekstovima) i čitateljima, a osobito njihovim horizontom očekivanja kada je u pitanju žanr autobiografskoga romana. To su govor u prvome licu, autodijegetički pripovjedač, faktografija, i sl. Struktura je Lovrakova autobiografskoga diskursa izrazito dinamična što se postiglo dominantnim nadilaženjem granica između predmetnoga i referentnoga teksta. $U$ tome se višestrukome nadilaženju, poigravanju granicama ustaljenih struktura i poznatih značenja, više nego u objektivnosti pristupa, krije kvaliteta ovoga Lovrakova teksta. Ne samo da ne želi odvojiti sebe od svojega djela, nego upravo suprotno - pisac podcrtava svaku i najmanju vezu svoga života s djelom prikazujući to iskustvo „sebe“ kao s djelom nedjeljivu cjelinu.

\section{Popis literature}

Bagić, Krešimir. 2012. Rječnik stilskih figura. Zagreb: Školska knjiga.

Biti, Vladimir. 2000. Pojmovnik suvremene književne i kulturne teorije. Zagreb: Matica hrvatska.

Brešić, Vinko. 1997. „Moj život - moja priča. Autobiografije hrvatskih pisaca“. U Autobiografije hrvatskih pisaca, 15-23. Zagreb: AGM.

Eigler, Friederike. 2002. „O statusu autobiografskog teksta“. Kolo (2). <http://www.matica. $\mathrm{hr} / \mathrm{kolo} / 289 / \mathrm{O} \% 20$ statusu\%20autobiografskog\%20teksta/> (pristup 30. siječnja 2015.).

Genette, Gérard. 2006. Metalepsa: od figure do fikcije. Prev. Ivana Franić. Zagreb: Disput.

Grakalić-Plenković, Sanja. 2014. „Autobiografije hrvatskih književnika u Almanahu srpskih i hrvatskih pjesnika i pripovjedača 1910“. U Riječki filološki dani 9. Zbornik radova, ur. Diana Stolac, 103-111. Rijeka: Filozofski fakultet. <https://bib.irb.hr/ datoteka/736476.11-RFD9_Grakalic-Plenkovic_Sanja.pdf $>$ (pristup 5. veljače 2015.).

Kuvač-Levačić, Kornelija. 2014. „Metalepsa i poigravanje funkcijama književnog teksta u humoreskama Bratoljuba Klaića“. Rasprave: Časopis Instituta za hrvatski jezik $i$ jezikoslovlje 40 (2): 551-567.

Kuvač-Levačić, Kornelija. 2016. „Metafore sebstva u autobiografskom diskursu Vesne Parun“. Nova prisutnost: časopis za intelektualna i duhovna pitanja 14 (2): 165-184.

Lejeune, Philippe. 2000. „Autobiografski sporazum“. U Autor, pripovjedač, lik, prir. Cvjetko Milanja, 201-236. Osijek: Svjetla grada i Sveučilište Josipa Jurja Strossmayera. $<$ http://uaos.hr/svi-obavijesti/Zbornik\%20-\%20Autor\%20pripovjedac\%20lik.pdf> (pristup 1. rujna 2015.).

Lešić, Zdenko. 2008. Teorija književnosti. Sarajevo: Sarajevo Publishing d.d.

Lovrak, Mato. 2014. Pero Kvržica među ljudima. Zagreb: Mozaik knjiga.

Medarić, Magdalena. 1993. „Autobiografija/Autobiografizam“. Republika 49 (7-8): 46-61.

Mirčev, Andrej. 2008. „Genološke kušnje“. Kolo (3). <http://www.matica.hr/kolo/309/ Genolo\%C5\%A1ke\%20ku\%C5\%A1nje/> (pristup 2. lipnja 2016.).

Olney, James. 1972. Metaphors of Self: The Meaning of Autobiography. Princeton: Princeton University Press. <http://www.scribd.com/doc/138926606/James-Olney-Metaphorsof-Self-The-Meaning-of-Autobiography\#scribd> (pristup 21. rujna 2015.). 
Sablić Tomić, Helena. 2002. Intimno i javno. Suvremena hrvatska autobiografska proza. Zagreb: Naklada Ljevak.

Zlatar, Andrea. 1998. Autobiografija u Hrvatskoj. Zagreb: Matica hrvatska.

\section{Kornelija Kuvač-Levačić}

University of Zadar, Zadar, Croatia

Universität Zadar, Zadar, Kroatien

\section{Subject identity in the fiction writer's autobiography and the "biography of a work of fiction": The case of Mato Lovrak's novel Pero Kvržica među ljudima, published in 2014}

The paper explores the construction of subject identity in Mato Lovrak's autobiographical discourse, using the novel Pero Kvržica među ljudima [Pero Knobble among people] (2014) as an example. Constructed in an intertextual manner - as a metatext of sorts - via the mediation of a (autoreferrential) narrative on the origin and reception of the author's most famous novel, Družba Pere Kvržice [Pero Knobble's Gang], Lovrak's autobiographical novel is analysed at the level of the object text (second-degree text), with Družba Pere Kvržice as its referent (first-degree text). The paper identifies strategies by which Lovrak's narration brings the notion of the merging of the author and his work - in complete contrast to theories which (whether partially or completely) deny such a unity - to the level of a symbolic function, deepening the complex issue of the textual construction of subject identity within the autobiographical discourse, especially when its author is a fiction writer. Further, the paper explores the use of a pseudo-heterodiegetic narrator, the role of the referent text, relations within the chain of communication (author - text - reader) and between documentarism and fictionality. The metaphor of the "biography of a work of fiction" presents the basis of the author's construction of "self" and functions as his primary element of identity which has an important influence on all major elements of the object text. The subject identity is construed in a documentary and fictional manner, while Lovrak's autobiographical discourse possesses the qualities of a sign which, in addition to structural elements and functions, engages in a playful interpretation of all the other elements of the literary communication chain.

Keywords: autobiographism, biography of a work of fiction, subject identity, autobiography of a fiction writer, Mato Lovrak

\section{Die Identität des Subjekts in der literarischen Autobiographie und in der, ,Werkbiographie"6 am Beispiel des 2014 veröffentlichten Romans Pero Kvržica među ljudima [dt. Pero Kvržica unter den Leuten] von Mato Lovrak}

Im Beitrag werden die Prozesse zur Bildung der Identität des Subjekts im autobiographischen Diskurs von Mato Lovrak am Beispiel seines Romans Pero Kvržica unter den Leuten (2014) erforscht. Anhand seines intertextuellen Aufbaus wird Lovraks autobiographischer Roman als eine Art Metatext auf der Ebene des Gegenstandtextes (des Textes auf zweiter Stufe) 
analysiert, während man seinen bekanntesten Roman Družba Pere Kvržice [dt. Pero Kvržicas Bande], über dessen Entstehung und Rezeption Lovrak in seinem autobiographischen Roman berichtet, als Referenztext (bzw. als Text auf erster Stufe) behandelt. Diesbezüglich wird auf die Verfahren hingewiesen, wodurch der in der Theorie teilweise oder vollständig abgelehnten Idee der Gleichstellung des Autors und seines Werkes eine symbolische Funktion zugewiesen wird, um in die komplexe Frage nach der textuellen Konstituierung der Identität des Subjekts im autobiographischen Diskurs, insbesondere wenn der Autor der Schriftsteller selbst ist, noch tiefer eindringen zu können. Zu diesem Zweck wird im Beitrag der Einsatz des pseudo-heterodiegetischen Erzählers, die Rolle des Referenztextes, die Beziehungen innerhalb der Kommunikation zwischen Autor, Textes und Leser sowie die Beziehung zwischen Dokumentarizität und Fiktionalität erforscht. Die Metapher von der „Werkbiographie“ liefert die Grundlage zur Autorkonstruktion „seiner selbst“, indem diese die primäre Identitätsbestimmung darstellt, die auf alle Grundbestimmungen des Gegenstandstextes wesentlich einwirkt. Die Identität des Subjekts wird dokumentarisch und fiktional konstruiert, wobei Lovraks autobiographischer Diskurs Charakteristiken eines offenen Zeichens aufweist, der nicht nur mit strukturellen Elementen und Funktionen, sondern auch mit allen anderen Bestandteilen der literarischen Kommunikation ein interpretatives Spiel betreibt.

Schlüsselwörter: Autobiographismus, literarische Autobiographie, Mato Lovrak, Subjektidentität, Werkbiographie 


\section{REPATA PRIČA}

Rep imade crni mačak,

Rep je njegov crn, dugačak,

Rep imade još i patak,

Ali rep je njegov kratak.

Rep imade još i svinja,

Rep od mesa i čekinja.

Rep ima i vjeverica,

Lagan kao pahuljica.

Ima zvijezda repatica

Rep od vatre i krijesnica.

Rep imade još i vlak -

Od sivoga dima trak.

Rep ima i mali bata

Onog trena,

Kad ostanu za njim vrata

Otvorena.

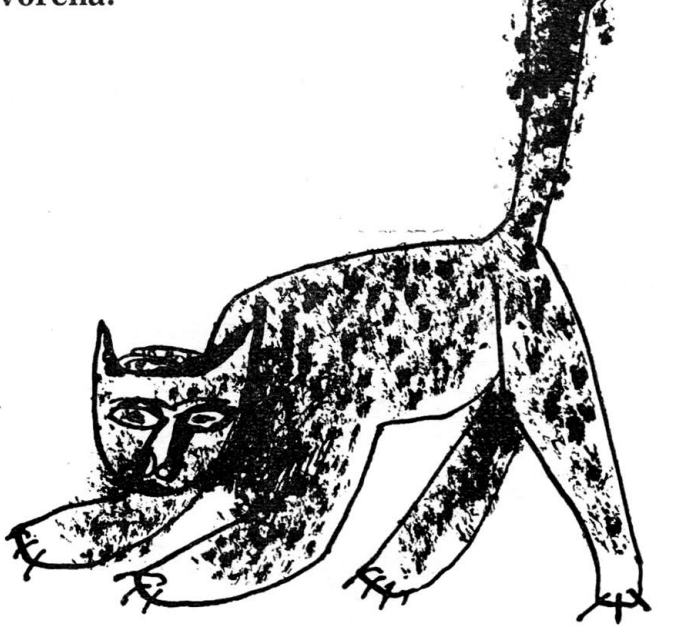

Biblioteka Vjeverica. / Book series Vjeverica.

Grigor Vitez. 1959. Kad bi drveće hodalo. Pjesnička zbirka. / A book of poetry.

Ilus. / Illus. Ivo Šebalj, str. / p. 35. 